\title{
Perancangan dan Realisasi Solar Tracking System untuk Peningkatan Efisiensi Panel Surya Menggunakan Arduino Uno
}

\author{
Kodrat Wirawan Fauzi ${ }^{1}$, Teguh Arfianto ${ }^{2}$, Nandang Taryana ${ }^{3}$ \\ ${ }^{1}$ Teknik Elektro Institut Teknologi Nasional Bandung \\ Jl. PHH. Mustafa No. 23 Bandung Jawa Barat Indonesia, +62 22 7272215/ +62 227202892 \\ ${ }^{2,3}$ Teknik Elektro Institut Teknologi Nasional Bandung \\ Jl. PHH. Mustafa No. 23 Bandung Jawa Barat Indonesia, +62 22 7272215/ +62 227202892 \\ kodratwirawanf@gmail.com ${ }^{1}$, teguh.arfianto@gmail.com ${ }^{2}$, Yanztar17@gmail.com ${ }^{3}$
}

\begin{abstract}
Abstrak - Pada saat ini panel surya sudah banyak digunakan di wilayah Indonesia, telah banyak dimanfaatkan untuk menghasilkan energi listrik, yaitu dengan menggunakan panel surya yang dapat mengubah energi matahari menjadi energi listrik. Dalam hal ini kebanyakan solar cell yang terpasang kebanyakan bersifat statis atau diam, mengakibatkan penyerapan energi matahari oleh solar cell kurang optimal. Untuk mendapatkan energi matahari yang maksimal, maka posisi panel surya tersebut harus selalu tegak lurus terhadap arah datangnya sinar matahari. Pada penelitian ini telah dirancang sistem mekanis yang dapat menggerakkan posisi panel surya agar selalu mengikuti arah pergerakan matahari yang diberi nama solar tracking system. Solar tracking system yang dibuat merupakan prototype, solar tracker ini berfungsi untuk mengoptimalkan penerimaan energi matahari oleh solar cell. Sistem ini bekerja dengan adanya 2 buah sensor peka cahaya (LDR) yang membaca pergerakan matahari ditempatkan di beberapa sudut pada panel surya, lalu output LDR terhubung pada pin analog arduino, arduino akan mengolah data dari sensor LDR sehingga motor akan menggerakan solar cell ke kiri atau ke kanan sesuai perintah. Ada beberapa komponen yang digunakan pada perancangan solar tracking system ini yaitu acccu, solar charge controller, voltage regulator dan sebuah $L C D$. Dari hasil penelitian dapat disimpulkan bahwa dengan menggunakan metoda solar tracking system, maka total jumlah energi yang dihasilkan lebih besar dibandingkan panel surya statis.
\end{abstract}

Kata Kunci: Panel Surya Dinamis, Sistem Pelacak Matahari, Arduino Uno, Solar tracker dengan sensor $L D R$

\section{Pendahuluan}

Kebutuhan masyarakat Indonesia akan energi listrik saat ini semakin tinggi, hal ini seiring dengan pertambahan jumlah penduduk dan juga kemajuan teknologi. Sehingga perusahaan listrik negara (PLN) gencar mensosialisasikan program hemat listrik dari pukul 17.00 hingga 22.00. Alasan PLN melakukan ini adalah untuk efisiensi energi terutama dalam menghadapi beban puncak pada jam tersebut. Menurut Energy Information Administrasion (EIA) memperkirakan pemakaian energi hingga tahun 2025 masih didominasi bahan bakar fosil yakni minyak bumi, gas alam dan batu bara. Meskipun cadangan batu bara masih cukup tinggi, tetapi penggunaan bahan bakar batu bara yang merupakan sumber penghasil emisi karbon dioksida secara global menyebabkan efek global warming. Penggunaan panel surya yang terpasang pada umumnya kebanyakan masih bersifat statis. Hal ini menyebabkan penerimaan matahari tidak optimal, Untuk memanfaatkan energi cahaya matahari dengan optimal maka panel surya harus mengikuti arah sinar matahari. Semakin besar intensitas cahaya matahari yang ditangkap oleh panel surya, maka semakin besar daya listrik yang dihasilkan, oleh karena itu perlu dibuat suatu sistem yang dapat membuat solar cell selalu mengikuti arah pergerakan matahari yaitu dengan solar tracking

TELKA, Vol.4, No.1, Mei 2018, pp. 64 75

ISSN (e): 2540-9123

ISSN (p): 2502-1982 
system. Panel surya yang mengkonversikan sinar matahari menjadi energi listrik akan di desain dengan sistem solar tracking system yang dikontrol menggunakan mikrokontroler Arduino uno. Untuk dapat merealisasi sistem tersebut di atas dibutuhkan beberapa sensor peka cahaya yang membaca arah datangnya cahaya dari beberapa sudut lalu sensor tersebut mengirimkan data terhadap mikrokontroler sehingga mikrokontroler akan menentukan posisi yang tepat agar panel surya mendapatkan cahaya yang maksimal. Dengan menggunakan solar tracker system tersebut maka akan bertambah efisiensi panel surya untuk menyerap sinar matahari.

\section{Tahapan Perancangan}

Tahapan perancangan merupakan proses kerja yang terjadi pada solar tracking system yang bertujuan mengoptimalkan penyerapan pada energi matahari. Diagram alir pada solar tracking system ini ditunjukan sebagai berikut :

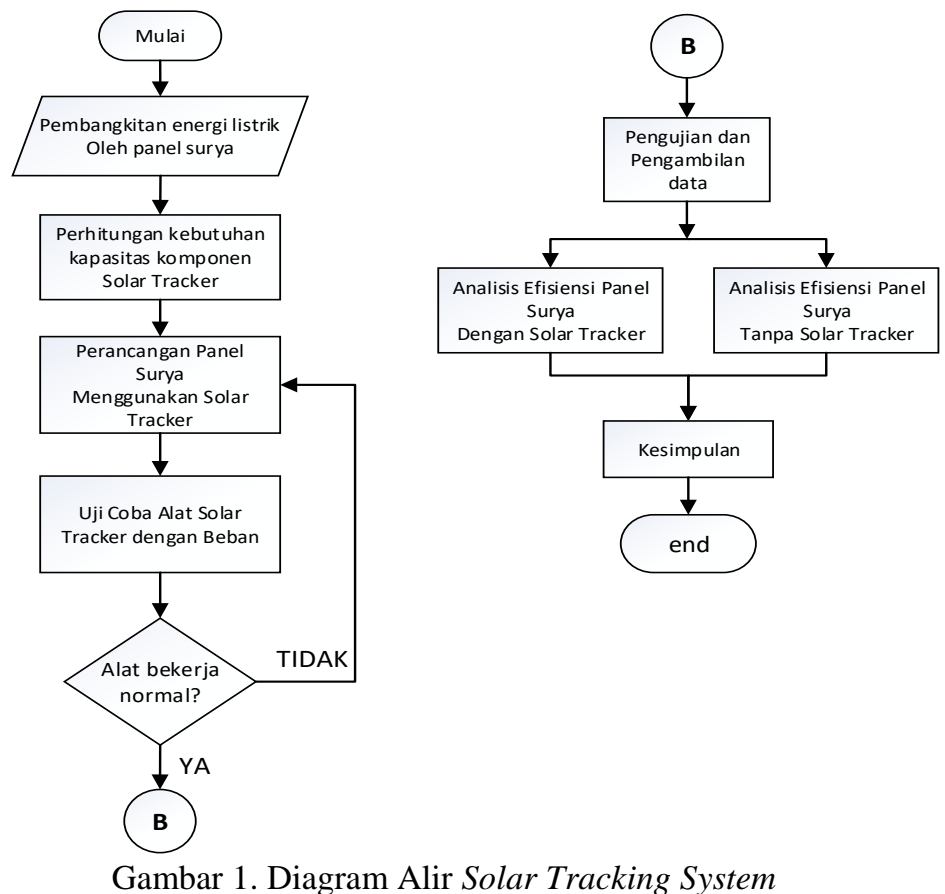

\subsection{Perancangan Solar tracker}

Pada pemodelan perancangan ini dijelaskan panel surya yang menggunakan solar tracker.

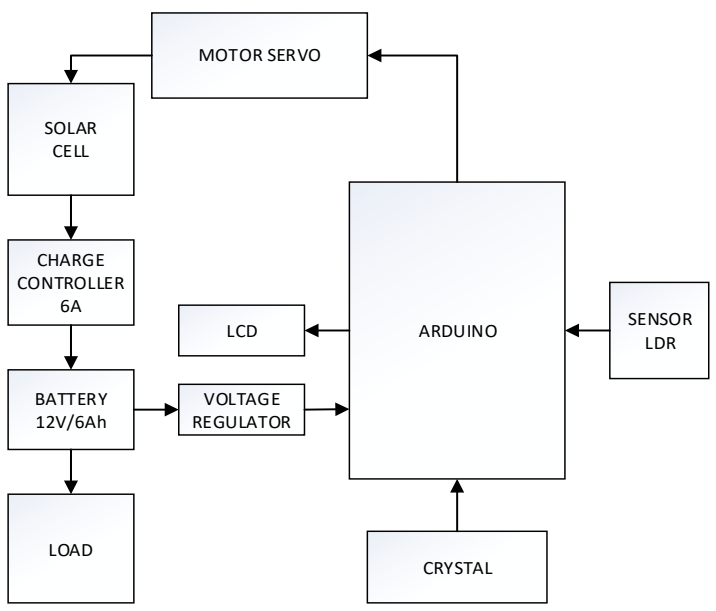

Gambar 2. Diagram Blok Perancangan Solar Tracking System 


\subsection{Penentuan Panel Surya}

Modul sel surya photovoltaic merubah energi surya menjadi arus listrik DC. Komponen utama sistem surya photovoltaic adalah modul yang merupakan unit rakitan beberapa sel surya photovoltaic. Panel surya pada perancangan solar tracker menggunakan panel Shinyoku 20WP (wattpeak) berbahan polycrystalline.

\section{Penentuan Solar Charge Controller}

Untuk perancangan ini dibutuhkan solar charge controller dengan tipe PWM dengan rating 6 ampere. Solar charge controller menerapkan teknologi Pulse width modulation (PWM) untuk mengatur fungsi pengisian baterai dan over-charging ke baterai. Beban pada sistem solar tracker mengambil energi dari charge controller.

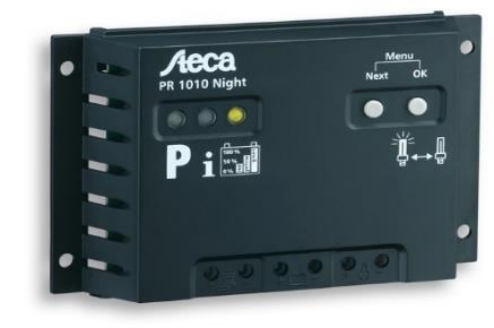

Gambar 3. Solar Charge Controller

\section{Baterai}

Baterai yang biasa digunakan untuk sistem fotovoltaik yaitu baterai lead acid SLI, lead acid low antimony dan nickel cadmium. Tetapi karena faktor harga dan sulitnya jenis baterai lead acid low antimony dan nickel cadmium dipasaran, maka dipilih jenis baterai VRLA (Valve Regulated Lead Acid) 12V/6Ah.

\section{Sistem sensor LDR}

Pada perancangan sistem ini menggunakan 2 buah sensor LDR dengan tipe fotokonduktif, LDR yang dipasang sebagai pelacak arah fokus datangnya sinar matahari di mana kedua sensor tersebut membentuk formasi garis sejajar. Pada perancangan ini LDR berfungsi sebagai pembanding kuat cahaya yang diterima oleh masing-masing sensor pada kondisi terfokusnya. Pada kondisi sebuah sensor mempunyai kepekaan terendah maka tracker akan bergerak menuju arah tersebut. Pada aplikasinya kedua sensor tersebut masing - masing dihubungkan pada pin analog Arduino uno, sehingga nilai dari masing-masing LDR dapat dibandingkan. Pada gambar 4 menunjukan skematik dan sistem rangkaian dasar sensor.

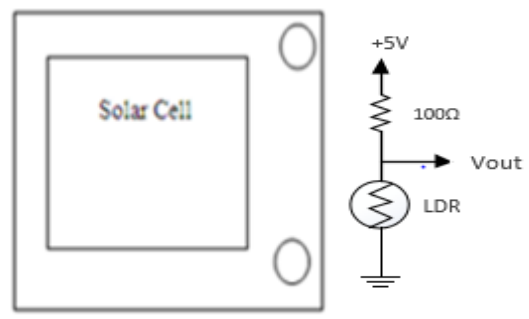

Gambar 4. Skematik LDR

\section{Sistem Rangkaian Arduino Uno}

Didalam rangkaian board arduino terdapat mikrokontroler AVR seri ATMega 328P yang merupakan produk dari atmel. Pada IC inilah semua program solar tracker diisikan, bahasa pemrograman arduino merupakan bahasa $\mathrm{C}$ yang sudah disederhanakan syntax bahasa 
pemrogramannya sehingga lebih mudah, sehingga perancangan ini dapat berjalan sesuai dengan yang dikehendaki. adapun spesifikasi data teknis yang terdapat pada board Arduino uno R3 adalah

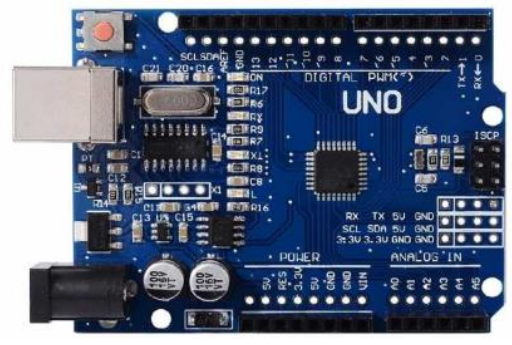

Gambar 5. Arduino Uno

\section{Penentuan LCD (Liquid Crystal Display)}

Dalam perancangan ini menggunakan LCD dengan tipe LCD LMB162ABC merupakan modul LCD dengan tampilan 2x16 (2 baris x 16 kolom) dengan konsumsi daya rendah. Modul tersebut dilengkapi dengan mikrokontroler yang didesain khusus untuk mengendalikan LCD. Seperti pada gambar 6 berikut:

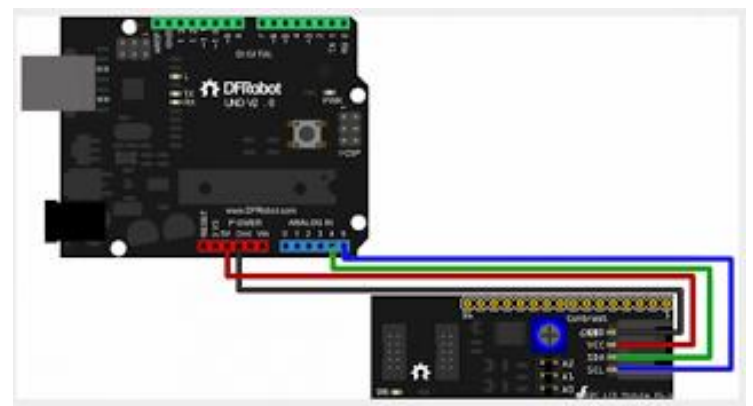

Gambar 6. Konektor I2C terhadap Arduino

Dari rangkaian diatas, shield LCD yaitu pin SCL pada i2c dihubungkan ke pin SCL Arduino uno dan pin SDA pada i2c dihubungkan dengan pin SDA Arduino uno. Vec dihubungkan ke 5V dan ground shield LCD ke ground Arduino uno. Pada Arduino uno pin SDA ada di pin A4 dan pin SCL ada di pin A5.

\section{Penentuan Motor Servo}

Perancangan solar tracker pada panel surya yang menggunakan motor servo dengan tipe towerpro MG995 untuk menggerakan panel surya, pada perancangan ini digunakan motor servo dikarenakan daya pemakaian motor servo lebih kecil dibandingkan dengan motor stepper.

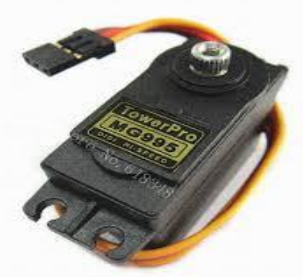

\section{Pengujian Komponen Solar Tracker}

Gambar 7. Motor Servo Towerpro MG995

Dalam pengujian rancang bangun ini dilakukan terlebih dahulu pengujian dari setiap komponen yang dipakai untuk merancang alat, pengujian ini meliputi : 


\subsection{Pengujian Sistem LDR}

Pengujian sensor cahaya ini dilakukan untuk mengetahui bagaimana respon sensor bekerja terhadap perubahan cahaya yang terjadi pada saat pengujian, pengukuran sensor LDR digunakan multimeter untuk mengukur output tegangan pada komponen tersebut. Pengujian ini dilakukan agar mengetahui berapa tegangan keluaran pada masing masing LDR. Skematik sensor LDR dapat dilihat pada gambar 8 .

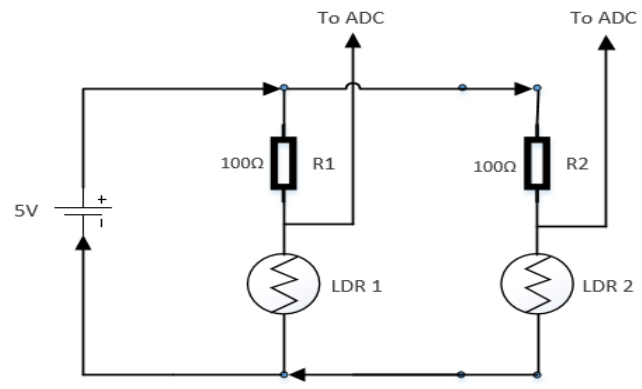

Gambar 8. Skematik Sensor LDR

Tabel 1. Pengukuran Sensor LDR

\begin{tabular}{cccc}
\hline Waktu & LDR 1 & LDR 2 & Posisi Panel Surya \\
\hline 8.00 & $1.32 \mathrm{~V}$ & $2.79 \mathrm{~V}$ & Posisi $30^{\circ}$ arah matahari \\
12.00 & $1.12 \mathrm{~V}$ & $1.17 \mathrm{~V}$ & Posisi $90^{\circ}$ arah matahari \\
16.00 & $2.87 \mathrm{~V}$ & $2.34 \mathrm{~V}$ & Posisi $150^{\circ}$ arah matahari \\
\hline
\end{tabular}

\subsection{Arduino Uno}

Pada perancangan solar tracking system ini arduino uno yang berfungsi untuk membaca input dari sensor LDR berupa nilai analog dengan rentang 0-1023 (10 bit). Jika output LDR 1 bernilai lebih rendah dibandingkan LDR 2, maka nilai analog dan nilai tegangan keluaran pada LDR 1 akan turun dikarenakan nilai analog berbanding lurus dengan output tegangan yang dihasilkan LDR. Sehingga board arduino mengolah data analog tersebut lalu akan memberi perintah dengan mengeluarkan sinyal PWM untuk mengontrol dan memberikan intruksi agar motor berputar ke arah timur.

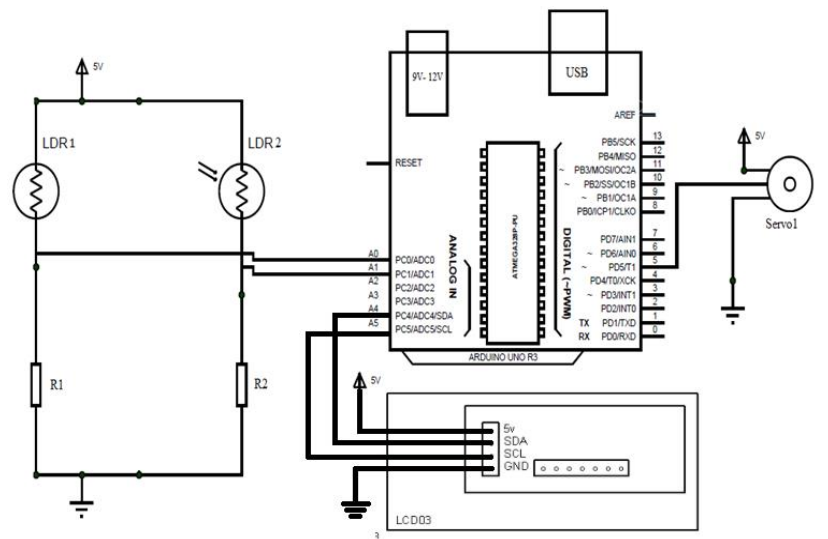

Gambar 9. Skematik Sistem Pada Arduino Uno

\section{Prinsip Kerja Panel Surya Pada Kondisi Statis}

Pengujian panel surya yang dirancang tanpa solar tracker atau dalam keadaan statis dengan cara membuat solar cell menghadap ke samping tidak mengikuti arah cahaya matahari, pada pengujian dan pengambilan data panel surya statis diletakan $30^{\circ} \mathrm{ke}$ arah timur dari pukul 08:00 hingga pukul 16:00, data pengujian ini diambil setiap setengah jam sekali. 


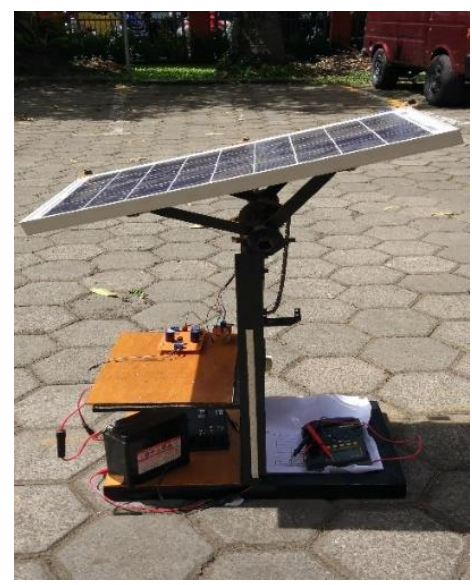

Gambar 10. Panel surya kondisi statis dengan kemiringan $30^{\circ}$

\section{Prinsip Kerja Panel Surya Pada Kondisi Dinamis (Solar Tracker)}

Pada perancangan yang dilakukan ini akan dijelaskan prinsip kerja alat solar tracking system. Pada perancangan sistem ini, menggunakan 2 buah sensor LDR dengan tipe fotokonduktif, LDR yang dipasang sebagai pelacak arah fokus datangnya sinar matahari di mana kedua sensor tersebut membentuk formasi garis sejajar. Pada perancangan ini LDR berfungsi sebagai pembanding kuat cahaya yang diterima oleh masing-masing sensor pada kondisi terfokusnya. Pada output sensor cahaya LDR 1 dihubungkan pada pin input analog A1 dan sensor cahaya LDR 2 pada pin input analog A2, ketika sensor cahaya LDR 1 terkena cahaya matahari maka output sensor LDR 1 berupa tegangan akan bernilai lebih kecil dibandingkan sensor LDR 2 begitupun sebaliknya. Perubahan pada nilai LDR 1 ini akan diolah oleh board arduino uno yang di dalam board tersebut terdapat mikrokontroler ATmega 328P yang berfungsi untuk mengolah data analog yang masuk. Ketika tegangan output sensor cahaya LDR berubah menjadi kecil, maka otomatis nilai analog dengan range (0-1023) akan menjadi kecil, sehingga board arduino yang telah dimasukan program solar tracker system dengan cara menghubungkan board arduino pada komputer / PC lewat software yang telah disediakan oleh arduino akan mengolah data analog tersebut, lalu arduino memberi perintah dengan mengeluarkan sinyal PWM (pulse width Modulation) untuk mengontrol dan memberikan intruksi agar motor servo berputar ke arah timur atau ke barat, ketika motor bergerak maka panel surya akan ikut bergerak berdasarkan cahaya matahari yang mengenai sensor LDR. Untuk menggerakan panel surya, dalam perancangan ini digunakan rancangan gear dan rantai untuk mengkopel motor servo dengan panel surya. Program solar tracker dirancang agar motor servo bergerak $2^{\circ}$ setiap 2 menit sekali lalu LDR 2 aktif untuk melakukan kalibrasi mencari intensitas cahaya tertinggi.

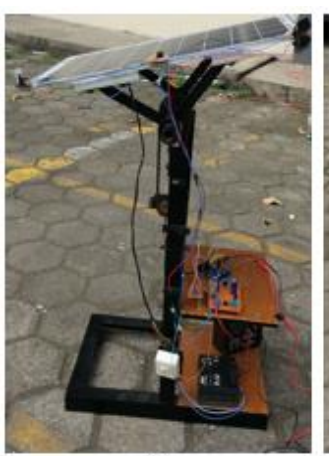

(a)

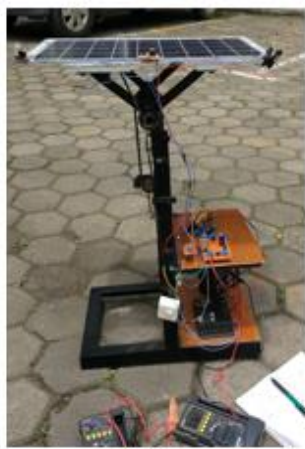

(b)

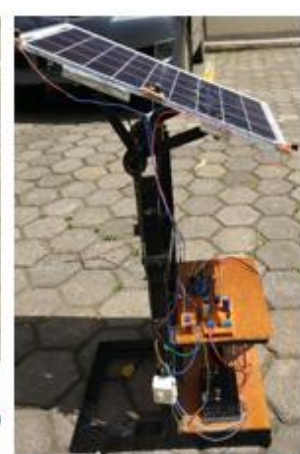

(c)

Gambar 11. Posisi Pergerakan Panel Surya Pada Kondisi Dinamis 


\section{Pengujian Panel Surya}

Pengujian pada panel surya ini dilakukan 2 tahap, yaitu panel surya yang dirancang tanpa solar tracker (statis) dan panel surya yang dirancang dengan solar tracker (dinamis). Data yang penulis ambil selama 8 jam dengan rata rata radiasi sinar matahari $1000 \mathrm{~W} / \mathrm{m}^{2}$ (intensitas sinar global saat radiasi maksimum).

\subsection{Pengujian Voc, Isc Keadaan Statis}

Pengujian pada tabel 2 berikut bertujuan untuk mengetahui kapasitas tegangan maksimum dan kapasitas arus maksimum dari panel surya yang dipakai. Pengujian tegangan hubung terbuka (Voc) dan arus hubung singkat (Isc).

Tabel 2. Pengukuran tegangan hubung terbuka, arus hubung singkat dan intensitas cahaya dan resistansi dalam pada keadaan statis

\begin{tabular}{|c|c|c|c|c|}
\hline $\begin{array}{c}\text { Waktu } \\
\text { (Jam) }\end{array}$ & $\begin{array}{l}\text { Voc } \\
\text { (V) }\end{array}$ & Isc (A) & $\begin{array}{c}\text { Intensitas } \\
\text { (Lux) }\end{array}$ & $\operatorname{Rd}(\Omega)$ \\
\hline 8.00 & 20.12 & 1.85 & 2260 & 10.87 \\
\hline 8.30 & 20.15 & 1.87 & 3140 & 10.77 \\
\hline 9.00 & 20.12 & 1.86 & 4780 & 10.81 \\
\hline 9.30 & 20.19 & 1.86 & 9100 & 10.85 \\
\hline 10.00 & 20.08 & 1.85 & 8850 & 10.85 \\
\hline 10.30 & 20.10 & 1.86 & 9000 & 10.80 \\
\hline 11.00 & 20.28 & 1.88 & 10320 & 10.78 \\
\hline 11.30 & 20.29 & 1.90 & 10260 & 10.67 \\
\hline 12.00 & 20.38 & 1.95 & 11990 & 10.45 \\
\hline 12.30 & 20.36 & 1.90 & 10990 & 10.71 \\
\hline 13.00 & 20.35 & 1.87 & 10750 & 10.88 \\
\hline 13.30 & 20.33 & 1.87 & 9190 & 10.87 \\
\hline 14.00 & 20.18 & 1.86 & 8660 & 10.84 \\
\hline 14.30 & 20.20 & 1.87 & 6640 & 10.80 \\
\hline 15.00 & 20.12 & 1.86 & 5220 & 10.81 \\
\hline 15.30 & 18.90 & 1.73 & 3080 & 10.92 \\
\hline 16.00 & 18.75 & 1.70 & 2440 & 11.02 \\
\hline$\Sigma$ & 20.05 & 1.86 & & \\
\hline
\end{tabular}

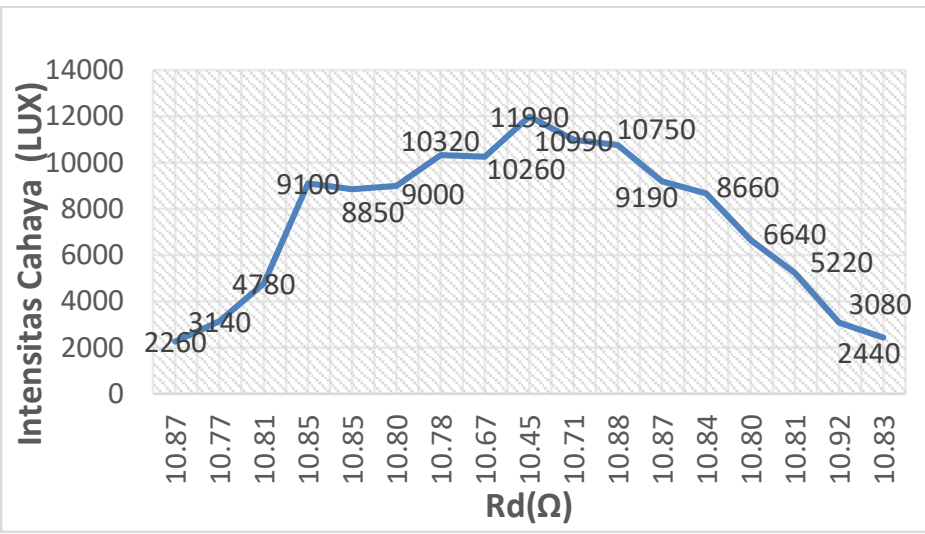

Gambar 12. Grafik hambatan terhadap intensitas cahaya matahari dalam keadaan statis

Pada grafik menunjukkan semakin tinggi nilai intensitas cahaya matahari maka semakin rendah nilai hambatan dalam pada solar cell. Sedangkan semakin rendah nilai intensitas cahaya matahari maka semakin tinggi nilai hambatan pada solar cell. 


\section{Pengujian Voc, Isc Keadaan Dinamis}

Pengujian panel surya menggunakan solar tracker atau dalam keadaan dinamis dengan cara membuat panel surya bergerak mengikuti arah matahari menggunakan rangkaian solar tracking system. Pada tabel 3 panel surya diuji dengan cara mengukur nilai intensitas cahaya, hambatan dalam, tegangan terbuka (open circuit) dan arus hubung singkat (short circuit) pada panel surya dengan menggunakan solar tracker (dinamis).

Tabel 3. Pengukuran tegangan terbuka, arus hubung singkat, intensitas cahaya dan tahanan dalam pada keadaan dinamis.

\begin{tabular}{ccccc}
\hline Waktu & $\begin{array}{c}\text { Voc } \\
(\mathbf{V})\end{array}$ & Isc (A) & $\begin{array}{c}\text { Intensitas } \\
(\text { Lux })\end{array}$ & Rd ( $\mathbf{\Omega})$ \\
\hline $\mathbf{8 . 0 0}$ & 20.30 & 1.80 & 3059 & 11.27 \\
$\mathbf{8 . 3 0}$ & 20.40 & 1.82 & 4480 & 11.20 \\
$\mathbf{9 . 0 0}$ & 20.54 & 1.84 & 6800 & 11.16 \\
$\mathbf{9 . 3 0}$ & 20.58 & 1.86 & 9250 & 11.06 \\
$\mathbf{1 0 . 0 0}$ & 20.70 & 1.88 & 9640 & 11.01 \\
$\mathbf{1 0 . 3 0}$ & 20.75 & 1.90 & 9920 & 10.92 \\
$\mathbf{1 1 . 0 0}$ & 20.80 & 1.90 & 10750 & 10.94 \\
$\mathbf{1 1 . 3 0}$ & 20.78 & 1.91 & 11800 & 10.87 \\
$\mathbf{1 2 . 0 0}$ & 20.90 & 1.98 & 13850 & 10.55 \\
$\mathbf{1 2 . 3 0}$ & 20.88 & 1.95 & 12560 & 10.70 \\
$\mathbf{1 3 . 0 0}$ & 20.75 & 1.89 & 11300 & 10.97 \\
$\mathbf{1 3 . 3 0}$ & 20.64 & 1.84 & 10450 & 11.21 \\
$\mathbf{1 4 . 0 0}$ & 20.60 & 1.83 & 9840 & 11.25 \\
$\mathbf{1 4 . 3 0}$ & 20.57 & 1.82 & 8400 & 11.30 \\
$\mathbf{1 5 . 0 0}$ & 20.50 & 1.80 & 6800 & 11.38 \\
$\mathbf{1 5 . 3 0}$ & 20.42 & 1.78 & 5500 & 11.47 \\
$\mathbf{1 6 . 0 0}$ & 20.38 & 1.75 & 4560 & 11.64 \\
$\Sigma$ & $\mathbf{2 0 . 6 2}$ & $\mathbf{1 . 8 6}$ & & \\
\hline
\end{tabular}

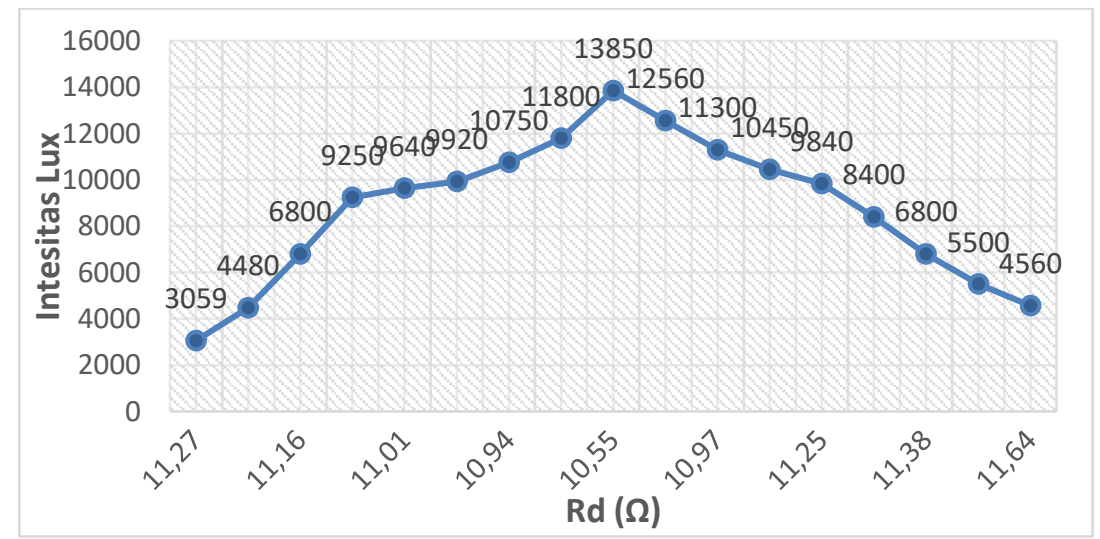

Gambar 13. Grafik hambatan terhadap intensitas cahaya matahari dalam keadaan dinamis

\section{Pengukuran Vm dan Im Pada Kondisi Statis}

Pengujian panel surya yang dirancang tanpa solar tracker atau dalam keadaan statis, dengan cara membuat solar cell menghadap ke atas tidak mengikuti arah cahaya matahari, pada pengujian ini panel surya diletakan $30^{\circ}$ ke arah timur di bawah matahari, 
Tabel 4. Pengukuran tegangan dan arus pada baterai dalam keadaan statis berbeban.

\begin{tabular}{ccccc}
\hline $\begin{array}{c}\text { Waktu } \\
\text { (Jam) }\end{array}$ & $\begin{array}{c}\text { Vp } \\
\text { (Volt) }\end{array}$ & $\begin{array}{c}\text { Vm } \\
(\mathbf{V})\end{array}$ & Im (A) & $\begin{array}{c}\text { P } \\
\text { (Watt) }\end{array}$ \\
\hline $\mathbf{8 . 0 0}$ & 13.39 & 13.30 & 1.18 & 15.69 \\
$\mathbf{8 . 3 0}$ & 13.45 & 13.36 & 1.19 & 15.89 \\
$\mathbf{9 . 0 0}$ & 13.50 & 13.41 & 1.20 & 16.09 \\
$\mathbf{9 . 3 0}$ & 13.47 & 13.34 & 1.28 & 17.07 \\
$\mathbf{1 0 . 0 0}$ & 13.41 & 13.35 & 1.34 & 17.88 \\
$\mathbf{1 0 . 3 0}$ & 13.42 & 13.35 & 1.35 & 18.00 \\
$\mathbf{1 1 . 0 0}$ & 13.45 & 13.30 & 1.32 & 17.56 \\
$\mathbf{1 1 . 3 0}$ & 13.50 & 13.36 & 1.38 & 18.43 \\
$\mathbf{1 2 . 0 0}$ & 13.53 & 13.41 & 1.55 & 20.78 \\
$\mathbf{1 2 . 3 0}$ & 13.49 & 13.38 & 1.45 & 19.40 \\
$\mathbf{1 3 . 0 0}$ & 13.34 & 13.26 & 1.38 & 18.29 \\
$\mathbf{1 3 . 3 0}$ & 13.31 & 13.24 & 1.35 & 17.87 \\
$\mathbf{1 4 . 0 0}$ & 13.30 & 13.23 & 1.34 & 17.72 \\
$\mathbf{1 4 . 3 0}$ & 13.30 & 13.24 & 1.30 & 17.21 \\
$\mathbf{1 5 . 0 0}$ & 13.12 & 12.98 & 1.25 & 16.22 \\
$\mathbf{1 5 . 3 0}$ & 13.05 & 12.83 & 1.20 & 15.39 \\
$\mathbf{1 6 . 0 0}$ & 12.95 & 12.80 & 1.15 & 14.72 \\
$\boldsymbol{\Sigma}$ & $\mathbf{1 3 . 3 5}$ & $\mathbf{1 3 . 2 4}$ & $\mathbf{1 . 3 1}$ & $\mathbf{1 7 . 3 1}$ \\
\hline
\end{tabular}

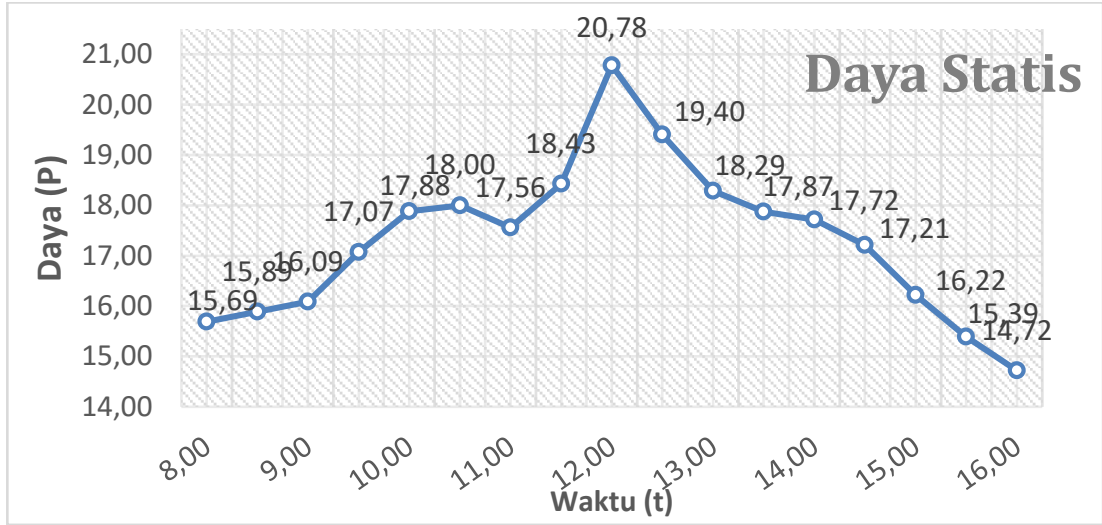

Gambar 14. Grafik hubungan daya terhadap waktu dalam keadaan statis

\section{Pengukuran Vm dan Im Pada Kondisi Statis}

Pengujian solar cell menggunakan solar tracker atau dalam keadaan dinamis dengan cara membuat panel surya bergerak menggunakan rangkaian solar tracker. Pada tabel 5 panel surya diuji dengan cara mengukur nilai tegangan tak berbeban $(\mathrm{Vp})$, tegangan berbeban $(\mathrm{Vm})$ dan arus berbeban (Im).

Tabel 5. Pengukuran tegangan dan arus pada baterai dalam keadaan dinamis berbeban

\begin{tabular}{ccccc}
\hline $\begin{array}{c}\text { Waktu } \\
\text { (Jam) }\end{array}$ & $\begin{array}{c}\text { Vp } \\
\text { (Volt) }\end{array}$ & $\begin{array}{c}\text { Vm } \\
\text { (Volt) }\end{array}$ & Im (A) & $\begin{array}{c}\text { P } \\
\text { (Watt) }\end{array}$ \\
\hline $\mathbf{8 . 0 0}$ & 13.10 & 13.05 & 1.27 & 16.57 \\
$\mathbf{8 . 3 0}$ & 13.21 & 13.15 & 1.30 & 17.10 \\
$\mathbf{9 . 0 0}$ & 13.30 & 13.25 & 1.40 & 18.55 \\
$\mathbf{9 . 3 0}$ & 13.36 & 13.30 & 1.52 & 20.22 \\
$\mathbf{1 0 . 0 0}$ & 13.46 & 13.41 & 1.60 & 21.46 \\
$\mathbf{1 0 . 3 0}$ & 13.57 & 13.50 & 1.74 & 23.49
\end{tabular}




\begin{tabular}{ccccc}
$\mathbf{1 1 . 0 0}$ & 13.56 & 13.51 & 1.75 & 23.64 \\
$\mathbf{1 1 . 3 0}$ & 13.61 & 13.55 & 1.76 & 23.85 \\
$\mathbf{1 2 . 0 0}$ & 13.75 & 13.68 & 1.88 & 25.72 \\
$\mathbf{1 2 . 3 0}$ & 13.74 & 13.65 & 1.82 & 24.84 \\
$\mathbf{1 3 . 0 0}$ & 13.55 & 13.40 & 1.70 & 22.78 \\
$\mathbf{1 3 . 3 0}$ & 13.44 & 13.30 & 1.65 & 21.95 \\
$\mathbf{1 4 . 0 0}$ & 13.38 & 13.28 & 1.65 & 21.91 \\
$\mathbf{1 4 . 3 0}$ & 13.35 & 13.26 & 1.60 & 21.22 \\
$\mathbf{1 5 . 0 0}$ & 13.26 & 13.15 & 1.57 & 20.65 \\
$\mathbf{1 5 . 3 0}$ & 13.16 & 13.08 & 1.35 & 17.66 \\
$\mathbf{1 6 . 0 0}$ & 13.12 & 12.91 & 1.25 & 16.14 \\
$\sum$ & $\mathbf{1 3 . 4 1}$ & $\mathbf{1 3 . 3 2}$ & $\mathbf{1 . 5 8}$ & $\mathbf{2 1 . 0 4}$ \\
\hline
\end{tabular}

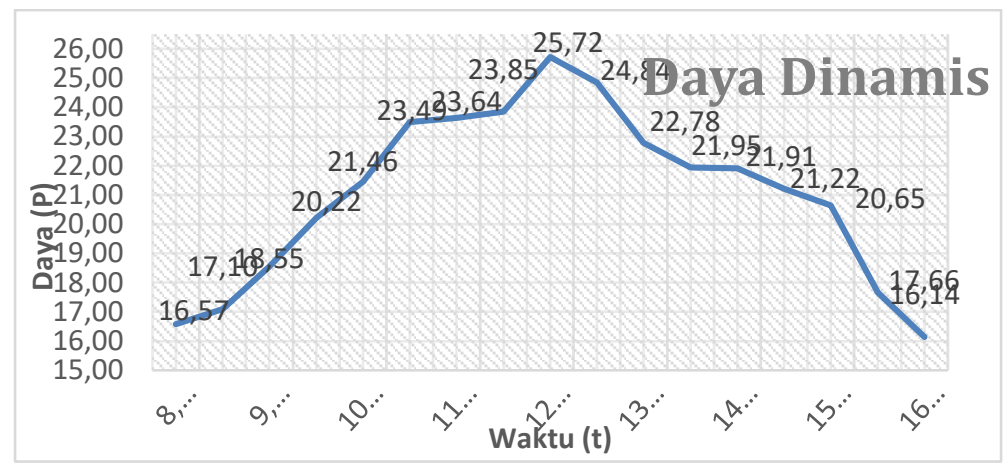

Gambar 15. Grafik hubungan daya terhadap waktu dalam keadaan dinamis

\section{Efisiensi Panel Surya Statis}

Untuk menentukan besarnya efisiensi panel surya kita harus mengetahui total daya foton (Pin) modul surya dan faktor pengisian (FF), untuk perhitungan total daya foton (Pin) sebagai berikut :

Tabel 6. Spesisifikasi Panel Surya Keadaan Statis

\begin{tabular}{cccc}
\hline $\mathbf{V m}(\mathbf{V})$ & $\mathbf{I m}(\mathbf{A})$ & $\mathbf{I s c}(\mathbf{A})$ & $\operatorname{Voc}(\mathbf{V})$ \\
\hline 13.24 & 1.31 & 1.85 & 20.05 \\
\hline
\end{tabular}

Untuk menentukan luas pada panel surya sebagai berikut :

$$
\begin{aligned}
\text { Luas } & =p \times l \\
& =0.535 \mathrm{~m} \times 0.345 \mathrm{~m} \\
& =0.1845 \mathrm{~m}^{2}
\end{aligned}
$$

Radiasi berdasarkan STC pada nameplate panel surya sebesar $1000 \mathrm{~W} / \mathrm{m}^{2}$ (intensitas sinar global saat radiasi maksimum), panel menghasilkan daya maksimum sebesar $20 \mathrm{wp}$. Untuk perhitungan faktor pengisian (FF) dapat ditentukan sebagai berikut :

$$
\begin{aligned}
& F F=\frac{V_{m p} \cdot I_{m p}}{V_{o c} \cdot I_{s c}} \\
& F F=\frac{13.24 \times 1.31}{20.05 \times 1.86} \\
& F F=0.46
\end{aligned}
$$

Dengan mengetahui luas panel surya dan faktor pengisian maka dengan persamaan (2) efisiensi panel surya statis dapat diketahui yaitu : 


$$
\begin{aligned}
\eta & =\frac{P_{\text {out }}}{P_{\text {in }}} \times 100 \% \\
& =\frac{20.05 \times 1.85 \times 0.46}{1000 \times 0.184 .5} \times 100 \% \\
& =\frac{17.46}{184.5} \times 100 \%
\end{aligned}
$$

\section{Efisiensi Panel Surya Dinamis}

Untuk menentukan besarnya efisiensi panel surya dinamis, kita harus mengetahui total daya foton (Pin) panel surya dan faktor pengisian (FF), untuk perhitungan total daya foton (Pin). Tabel dibawah menunjukan pengukuran tegangan dan arus menggunakan solar tracker (dinamis) sebagai berikut :

Tabel 7. Spesifikasi Panel Surya Keadaan Dinamis

\begin{tabular}{cccc}
\hline $\mathbf{V m}(\mathbf{V})$ & $\mathbf{I m}(\mathbf{A})$ & $\operatorname{Isc}(\mathbf{A})$ & $\operatorname{Voc}(\mathbf{V})$ \\
\hline 13.32 & 1.58 & 1.86 & 20.62 \\
\hline
\end{tabular}

$$
\begin{aligned}
& F F=\frac{V_{m} \cdot I_{m}}{V_{\text {oc. }} I_{s c}} \\
& F F=\frac{13.32 \times 1.58}{20.62 \times 1.86} \times 100 \%
\end{aligned}
$$

Dengan mengetahui luas panel surya dan faktor pengisian maka efisiensi panel surya dinamis dapat diketahui yaitu :

$$
\begin{aligned}
\eta=\frac{P_{\text {out }}}{P_{\text {in }}} \times 100 \% & =\frac{V_{\text {oc. }} I_{S c . F F}}{S . F} \times 100 \% \\
& =\frac{20.62 \times 1.86 \times 0.54}{1000 \times 0.1845} \times 100 \% \\
& =\frac{15.5}{184.5} \times 100 \% \\
& =11.22 \%
\end{aligned}
$$

\section{Kesimpulan}

Berdasarkan hasil percobaan dan pembahasan terhadap data yang telah diperoleh maka pada bab ini dapat ditarik kesimpulan:

1. Dari hasil pengujian solar cell, dengan menggunakan solar tracker, energi matahari dapat diserap lebih optimal dibandingkan dengan tanpa menggunakan solar tracker (statis). Daya maksimum yang diserap pada pukul 12.00 oleh panel surya statis adalah 16.62 Watt, sedangkan yang diserap panel surya dinamis adalah 25.72 Watt.

2. Dari hasil pengujian panel surya menggunakan solar tracker mempunyai selisih $2 \%$ antara panel surya statis dan dinamis. Maka solar tracker system berpengaruh pada penyerapan panel surya.

3. Tahanan dalam dari solar sel tergantung dari nilai intensitas cahaya matahari. Pada pengujian panel surya dinamis, nilai intensitas cahaya rendah terjadi pada pukul 08.00 dengan nilai 3058 Lux maka tahanan dalam dari solar sel akan semakin meningkat yaitu $11.27 \Omega$ dan nilai intensitas cahaya matahari semakin kuat terjadi pada pukul 12.00 dengan nilai 13850 , maka tahanan dalam dari solar sel akan semakin menurun dengan nilai $10.87 \Omega$.

4. Menggunakan LDR dengan tipe fotokonduktif, merupakan sensor yang peka terhadap cahaya dapat digunakan untuk membandingkan tingkat intensitas energi yang mengenainya, yaitu dengan menggunakan 2 buah LDR dan membandingkan nilai intensitas dari masing-masing LDR. 


\section{Daftar Pustaka}

[1] Swetash Mani Shrivastava, Dual Axis Solar Tracker, 2013

[2] Frank D, Petruzella. 1996. Industrial Elektronics. International Editions. Singapore: Glencoe / McGraw-Hill.

[3] Benny, Perancangan Dan Realisasi Kebutuhan Kapasitas Baterai Untuk Beban Pompa Air 125 Watt Menggunakan Pembangkit Listrik Tenaga Surya, 2015

[4] Yudhi Andrian, Solar Tracking System Untuk Penyerapan Energi Matahari Pada Panel Surya

[5] Fadhlullah, Khalid. Solar Tracking System Berbasis Arduino, Skripsi, Universitas Islam Negeri Alauddin Makassar, 2017

[6] Dhomo, Dedy. Pemanfaatan Mikrokontroler Sebagai Pengendali Solar Tracker Untuk Mendapatkan Energi Maksimal. 2007 Sistem Pelacak Matahari Menggunakan Arduino, Universitas Narotama Surabaya.

[7] Nugroho, Alexander. Modul ATmega 328P

[8] Electronics maker, Design of Automatic Solar Tracking Prototype 